\title{
Editorial: Caring for dairying
}

\author{
Christopher H Knight
}

University of Copenhagen Faculty of Medical Sciences, DK1870 Frb C, Denmark

'Animal wellbeing is at the start of a chain that links to farmer profitability, product quality, consumer satisfaction and environmental sustainability'. This is the opening statement and raison d'être of DairyCare, an EU COST-funded network of researchers dedicated to developing technology-based solutions for improving the health and welfare of dairy animals. Technology solutions are complex (so the network includes experts from many disciplines including animal scientists, computer technologists, veterinarians, electronics engineers, ethologists and social scientists) and culturally diverse (DairyCare has members in 30 EU COST countries as well as Australia, New Zealand, USA and Canada). Funding for the Action has now come to an end, but the networking continues through the website (http:// www.dairycareaction.org) and over the next year or so the outputs will be disseminated to scientific, end-user and lay audiences. Here at Journal of Dairy Research we have already been involved through a major review of wellbeing technologies (Caja et al. 2016), a short but nevertheless highly impactful account of changes in milk cortisol as a response to management changes (Pošćić et al. 2017) and an analysis of salivary biomarkers indicative of heat stress (Lamy et al. 2017). Over the coming months we shall be publishing much more, including an overall assessment of the status and future for technological husbandry support. DairyCare organized five major international Conferences as well as a number of focused Workshops and covered a range of topics including stress monitoring, sub-acute ruminal acidosis, social behavior, lameness and metabolic problems, all from the standpoints of biomarker-based technologies, activity-based technologies and systems level integration. The importance of animal wellbeing as a societal and commercial issue cannot be overemphasized, and the role that technology might play in optimizing wellbeing has featured in many of our recent issues (see, for example, Ammer et al. 2016; Schüller \& Heuwieser, 2016; D'Andrea et al. 2017; Moretti et al. 2017; Steensels et al. 2017a, b) as well as in two Editorials (Hillerton, 2016; Agenäs, 2017). The global expansion of dairying and especially the expected increase in average herd size will make increasing demands on technology in the future, and as a Journal we are committed to helping meet those demands. Our 'caring' instincts are by no means restricted to dairy animals. In the current issue we feature

For correspondence; e-mail: chkn@sund.ku.dk our first Cluster of research articles, comprising a short landscaping review accompanied by several (in this case, six) related research communications. The topic is the 'health' of dairy processing plants, particularly with regard to water consumption and with a focus on Ireland (Finnegan et al. 2018). We welcome proposals for Clusters from other Consortia, particularly international groupings working in cross-disciplinary topics. Whilst Ireland might be the most prolific contributor to this latest issue, we are gratified to be including five articles that include authors from the USA and three from each of France and India. As for cross-disciplinarity, the application of neuronal network modeling to understand protein hydrolysis in dairy products (Espejo-Carpio et al. 2018) might have taken some beating, had they been actual neurones!

\section{References}

Agenäs A 2017 Editorial: we need to bring the calves back to the dairy cows. Journal of Dairy Research $\mathbf{8 4} 239$

Ammer S, Lambertz C \& Gauly M 2016 Comparison of different measuring methods for body temperature in lactating cows under different climatic conditions. Journal of Dairy Research 83 165-172

Caja G, Castro-Costa A \& Knight CH 2016 Engineering to support wellbeing of dairy animals. Journal of Dairy Research 83 136-147

D'Andrea L, Guccione J, Alsaaod M, Deiss R, Di Loria A, Steiner A \& Ciaramella P 2017 Validation of a pedometer algorithm as a tool for evaluation of locomotor behaviour in dairy Mediterranean buffalo. Journal of Dairy Research 84 391-394

Espejo-Carpio FJ, Pérez-Gálvez R, Guadix A \& Guadix EM 2018 Artificial neuronal networks (ANN) to model the hydrolysis of goat milk protein by subtilisin and trypsin. Journal of Dairy Research $\mathbf{8 5}$

Finnegan W, Clifford E, Goggins J, O'Leary N, Dobson A, Rowan N, Xiao L, Miao S, Fitzhenry K, Leonard P, Tarpey E, Gil-Pulido B, Gao F \& Zhan X 2018 Dairywater: striving for sustainability within the dairy processing industry in the Republic of Ireland. Journal of Dairy Research 85

Hillerton JE 2016 Editorial: dairy animal health - turning problems into opportunities. Journal of Dairy Research $\mathbf{8 3} 135$

Lamy E, Jurkovich V, Rodrigues L, Geraldo A, Cachucho L, Silva F, Matos C, Silva FC, Pinheiro C, Könyves L, Bakony M \& Pereira A 2017 Detection of $70 \mathrm{kDa}$ heat shock protein in the saliva of dairy cows. Journal of Dairy Research 84 280-282

Moretti R, Biffani S, Tiezzi F, Maltecca C, Chessa S \& Bozzi R 2017 Rumination time as a potential predictor of common diseases in high-productive Holstein dairy cows. Journal of Dairy Research $\mathbf{8 4}$ 385-390

Pošćić N, Gabai G, Stefanon B, Da Dalt L \& Sgorlon S 2017 Milk cortisol response to group relocation in lactating cows. Journal of Dairy Research 84 36-38

Schüller LK \& Heuwieser W 2016 Measurement of heat stress conditions at cow level and comparison to climate conditions at stationary locations inside a dairy barn. Journal of Dairy Research 83 305-311 
Steensels M, Maltz E, Bahr C, Berckmans D, Antler A \& Halachmi I 2017a Towards practical application of sensors for monitoring animal health: The effect of post-calving health problems on rumination duration, activity and milk yield. Journal of Dairy Research 84 132-138
Steensels M, Maltz E, Bahr C, Berckmans D, Antler A \& Halachmi I 201 7b Towards practical application of sensors for monitoring animal health; design and validation of a model to detect ketosis. Journal of Dairy Research 84 139-145 